\title{
Hydraulic stability evaluation of a diaphragm wall in granular soils recharged by an unconfined aquifer
}

\section{Evaluación de la estabilidad hidráulica de un muro pantalla en suelos granulares recargados por un acuífero no confinado}

Fecha de entrega: 6 de enero 2014

Fecha de aceptación: 28 de abril 2014

\section{David Mozó ${ }^{1}$, Paulo Oróstegui ${ }^{2}$ and Felipe Villalobos ${ }^{3}$}

${ }^{1}$ Constructora Lancuyen, Barros Arana 492, of. 63, Concepción, Chile, dmozo@lancuyen.cl

${ }^{2}$ OITEC, Engineering, Surveying and Geotechnics, Lincoyan 444, of. 309, Concepción, Chile, porostegui@oitec.cl

${ }^{3}$ Laboratory of GeoMaterials, Catholic University of Concepción, Alonso de Ribera 2850, Casilla 297 Concepción, Chile, avillalobos@ucsc.cl

Diaphragm walls are normally adopted for deep basements in granular soils because, among other reasons, they act as watertight retaining structures and can form part of the structure foundations. When the water table is high and the excavation is deep there is a likely risk of hydraulic stability problems. In this work two-dimensional flow nets around a diaphragm wall of $20 \mathrm{~m}$ depth and 0.8 $m$ thickness are studied for different construction/ excavation stages. The water level behind the wall is the result of the excavation geometry, soil permeability and aquifer characteristics, i.e. a horizontal water level is not imposed. Using a commercial 2D steady flow software, distributions of velocities and hydraulic gradients are determined. Based on the definition of piping safety factor, a maximum excavation depth and a diaphragm wall minimum embedment are determined. Results using an isotropic coefficient of permeability value are compared with the anisotropic case. Hydrodynamic pressures over the wall are also determined and compared with hydrostatic pressures. Finally, it is pointed out that a minimum diaphragm wall embedment should be verified to avoid piping or erosion effects, which can be detrimental for the stability of the project during construction.

Keywords: diaphragm wall, seepage, piping, factor of safety, hydraulic gradient
Muros pantalla son normalmente elegidos para subterráneos profundos en suelos granulares porque entre otras razones, ellos sirven como estructura de contención impermeables y pueden formar parte de las fundaciones de la estructura. Cuando el nivel freático es alto y la excavación es profunda existe un probable riesgo de problemas de estabilidad hidráulica. En este trabajo se estudian redes de flujo bidimensionales alrededor de un muro pantalla de $20 \mathrm{~m}$ de profundidad $y$ $0.8 \mathrm{~m}$ de espesor para diferentes etapas de construcción/ excavación. El nivel freático detrás del muro es el resultado de la geometría de la excavación, permeabilidad del suelo y características del acuifero, es decir, no se impone un nivel horizontal del nivel freático. Se determinan distribuciones de velocidades y gradientes hidráulicos usando un programa computacional comercial de flujo estacionario 2D. Basándose en la definición de factor de seguridad de piping, se determina una profundidad de excavación máxima y un empotramiento mínimo del muro pantalla. Se comparan estos resultados usando valores del coeficiente de permeabilidad isotrópico y anisotrópico. También se determinan presiones hidrodinámicas sobre el muro, las cuales son comparadas con las presiones hidrostáticas. Finalmente, se señala que se debe verificar un empotramiento mínimo del muro pantalla para asi evitar piping o efectos de erosión, los cuales pueden ser perjudiciales para la estabilidad del proyecto durante su construcción.

Palabras clave: muro pantalla, escurrimiento, factor de seguridad, piping, gradiente hidráulico 


\section{Introduction}

Diaphragm walls have been increasingly adopted worldwide for deep basements because they can act as a retaining watertight structure and form part of the building foundations. Additionally, this geotechnical solution can reduce significantly the time of construction, soil vibration and machinery noise during construction. Wall dimensions are normally controlled by the structural analysis and construction equipments available. Reports of calculations and designs based on standard codes are commonly produced (e.g. EAB, 2008; NCh 3206, 2010), which are basically the solution to resist static and seismic earth pressures and hydrostatic pressures against the wall. Briefly, this results in detailed plans and drawings of the wall and steel bars for the wall (and dimensions of anchors or props). Due to the large earth and water pressures applied, diaphragm walls can be easily between 0.4 up to $1 \mathrm{~m}$ of thickness and hence the amount of steel bars can be considerable. Structural engineers generally argue about this large amount of steel which needs to be integrated with smaller structural elements above the ground. Moreover, great attention is also paid to the construction because it is a complicated task in terms of equipments and techniques to dig stable trenches to make sequences of wall panels.

In addition, studies of hydraulic stability are carried out when relatively high groundwater levels are found. Stability studies of the excavation bottom are normally evaluated using the traditional assumption of horizontal phreatic level behind the wall. The wall embedment is evaluated by means of a seepage analysis, which involves the determination of flownets, hydraulic gradients, hydrodynamics pressures and flow rates. It is customary to adopt a factor of safety for piping and hydraulic heave. The former corresponds to the ratio between the critical hydraulic gradient and the actual hydraulic gradient at a particularly point such as the excavation bottom. This analysis will be pursued in this study. The latter is the Terzaghi method determined as the ratio between the weight of the soil next to the wall on the excavation side and the upwards force imposed by the water flow which tries to uplift the soil. Hydraulic base failure occurs when cohesionless soils in front of the toe of a retaining wall become weightless due to upward directed seepage pressure, or when the upward directed pressure is equal to the sum of the soil weight density and additional restraining forces $(\mathrm{EAB}, 2008)$. This analysis will not be undertaken in this study (for the application of this method see for example Aulbach and Ziegler, 2013a,b). The safety factor procedure allows the assessment of the maximum excavation depth and the minimum wall embedment (for a fixed wall depth), with the aim of reducing the risk of piping failure leading to excavation bottom failure. Other alternative, which will not be analysed in this study, based on a fixed excavation depth, is the determination of the minimum wall embedment depth. This may be the case for instance in projects where the number of underground levels is predefined and unchangeable.

The flow rate can be also calculated from the flow net and used for the dewatering system design in order to keep dry the excavation bottom. The adopted dewatering system should not excessively pump inducing piping and transport of fine grains and therefore increasing the voids in the soil, especially around the wall. The collapse of the Cologne archive in Germany, it has remarked the catastrophic type of failure that a diaphragm wall in granular soil can suffer due to hydraulic instability. It is believed that excessive pumping may have induced piping erosion instability (NCE, 2009; GE, 2009).

In this paper the hydraulic stability and flow rates considering the geometry, boundary conditions and excavation sequence shown in Figure 1 are studied. The phreatic level behind the diaphragm wall is not forced to be horizontal, but it is the result of the excavation geometry, soil permeability and the recharge distance of an unconfined aquifer. The conditions and characteristics adopted are a hypothetical example that represents a geological simplification. Because of the symmetry of the problem half of the cross section is analysed as shown in Figure 1. An initial water table depth at $2 \mathrm{~m}$ and an impervious border depth at $40 \mathrm{~m}$ are considered; the vertical axis of symmetry represents an impervious border. This will be obviously different for each project and the intention here is to present a methodology that can be applied to other similar cases. 


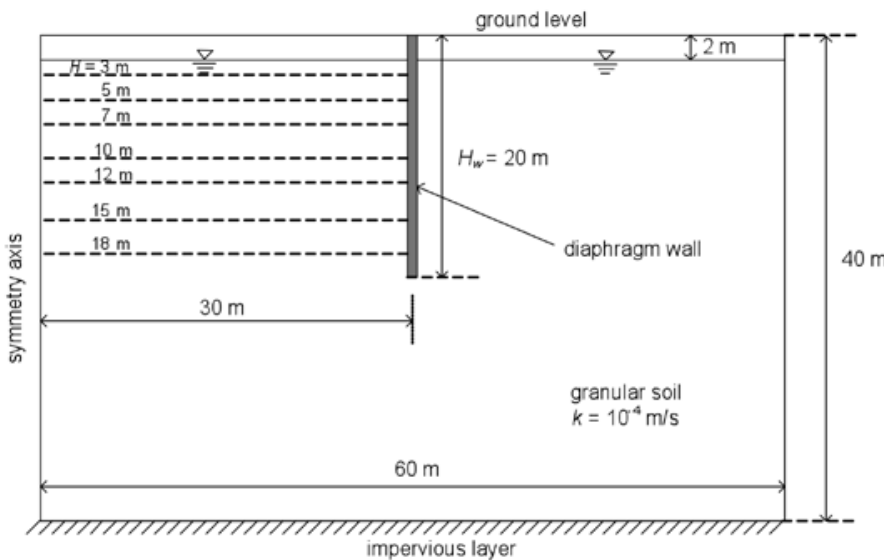

Figure 1: Boundary conditions and excavation sequence for the diaphragm wall analysis

\section{Rechargeable and not rechargeable uncon- fined aquifers}

The classical seepage problem around sheetpiles set out by Terzaghi (1943) assumes a rechargeable unconfined aquifer, in such a form that the water table (top flow line behind the wall) keeps horizontal during steady flow. This assumption has been used in subsequent studies (e.g. McNamee, 1949; Marsland, 1953; Griffiths, 1994; Ziegler et al., 2009; Aulbach and Ziegler, 2013a,b) and also in excavation recommendations (e.g. BS 8004, 1986; EAU, 2006; EAB, 2008). Figure 2a shows a flownet for this case, i.e. an unconfined aquifer where the recharge occurs laterally from the aquifer as well as vertically from a source above such as rain or by addition of pumped water from the excavation. If the excavation is next to the border of a water body such as a river, sea or lake, the water level behind the wall is practically horizontal and this assumption is valid. It is also applicable when the permeability is low, the excavation is dug rapidly or the excavation is small.

However, this is not necessarily the case when, for instance, the rain and pumped water is diverted to the city drain system and therefore flowing away from the excavation site or not ponded conditions exist behind the wall. For this reason in Figure $2 b$ there is only the unconfined aquifer with horizontal recharge and this flow net reflects this difference. Bearing in mind that when water is pumped from wells the water table surface around the well adopts an inverted cone shape or a parabolic shape in earth dams, a similar drop of the water surface also occurs behind excavations. Powrie (2004) refers to the flownets in Figure $2 \mathrm{a}$ and $2 \mathrm{~b}$ as confined and unconfined flownets, respectively.
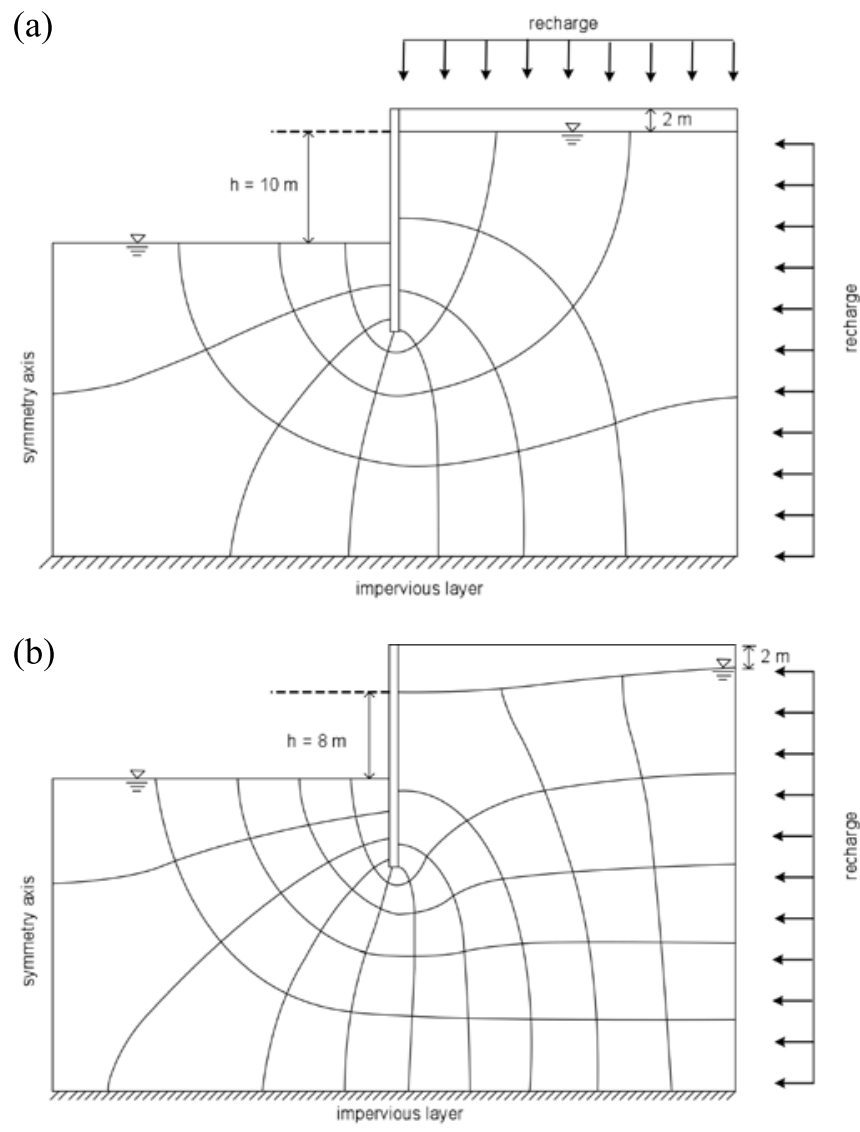

Figure 2: Flownets around a diaphragm wall when the excavation is $12 \mathrm{~m}$ deep, showing the effect of: a) steady vertical and lateral recharges and b) only lateral recharge from an unconfined aquifer

It is worth pointing out that the drawdown in the unconfined flownet depends on the soil permeability, time (although the final value corresponds to a steady condition) and the excavation geometry and in particular the right hand border distance, $30 \mathrm{~m}$ in this case. The drawdown increases with this distance reaching a point where stabilises. This analysis is not carried out in this study, which is part of ongoing research.

\section{Conditions and case of analysis}

In this study an already built $20 \mathrm{~m}$ deep and $0.8 \mathrm{~m}$ thick diaphragm wall in granular soil as well as a water table of $2 \mathrm{~m}$ below the ground surface are considered (Figure 1). The commercial computer software GGU-SS-FLOW 
2D (2008) was used to calculate parameters such as hydraulic gradient, flow rate into the excavation, flow velocity and hydrodynamic pore pressure against the wall. This software allows analyses of steady flow under plane condition using the Finite Element Method FEM. Although the Finite Difference Method is normally used for seepage problems, FEM can adapt better to complicated boundary and geometry conditions as well as being numerically more stable (Powrie, 2004; GGU-SS-FLOW 2D, 2008).

The calculation of these parameters was performed for a progressive excavation as depicted in Figure 1. The water flow below the wall is proportional to the hydraulic head $\Delta h$ (difference between the water table behind the wall and the excavation level). Thus, when the excavation depth $H>2 \mathrm{~m} \rightarrow \Delta h>0$. It is assumed that there is a dewatering system to pump the water out of the excavation to keep just dry the excavation bottom without inducing piping. The soil is considered isotropic, i.e. the coefficient of permeability has the same value in any direction $k=k_{v}=$ $k_{h}=10^{-4} \mathrm{~m} / \mathrm{s}$. This value of $k$ is representative of granular alluvial and fluvial deposits.

\section{Hydraulic gradients}

For an excavation depth of $12 \mathrm{~m}$, Figure 3 shows equipotential lines and velocity vectors results determined using the computer program GGU-SS-FLOW 2D (2008).

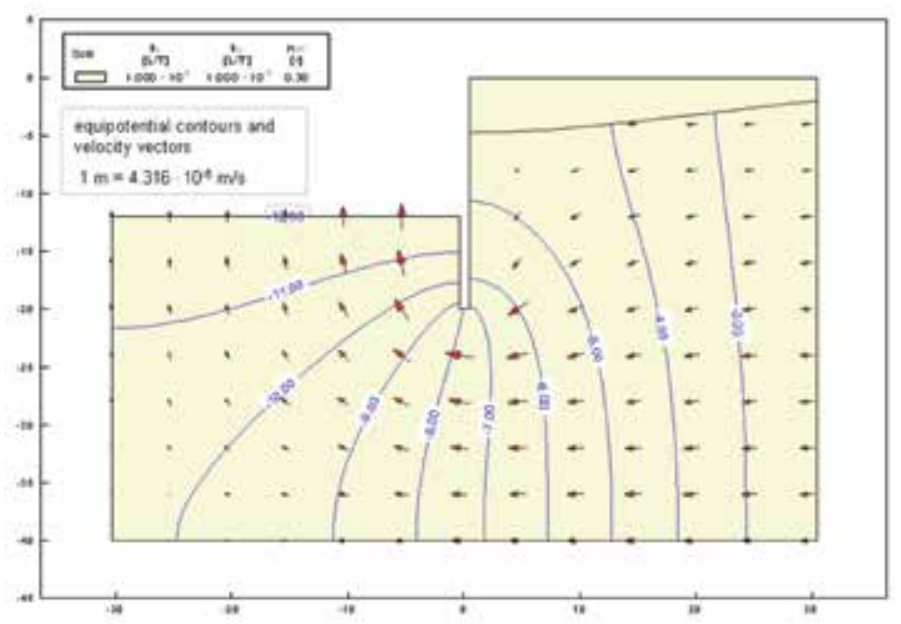

Figure 3: Equipotential lines and flow velocity vectors for an excavation of $12 \mathrm{~m}$

Figure 4 shows the distribution of hydraulic gradients $i$ around the diaphragm wall when the excavation is $12 \mathrm{~m}$ deep. The highest values of $i$ occur below the wall toe, albeit it is of particular interest at the excavation bottom next to the wall. In Figure 4 a zoom of the bottom of the wall is shown on top right, where $i$ reaches a value of 0.6 in average, but just underneath the wall toe $i$ approaches values even slightly above 1 . Since a value of $i$ close to 1 corresponds to a critical hydraulic gradient $i_{c r}$ (a sand with a buoyant unit weight $\gamma^{\prime}=10.2 \mathrm{kN} / \mathrm{m}^{3} \rightarrow i_{c r}=\gamma^{\prime} / \gamma_{w}$ $=10.2 / 9.8=1.04 \approx 1$ ), it should be verified that this zone with $i_{c r}$ close to one does not propagate to the surface developing a piping failure. Since the value of $i$ is around 0.3 in the soil below the excavation and next to the wall no piping propagation should be expected. It is worth pointing out that Harr (1990) indicates values of 4 and 5 as reasonable for a piping factor of safety defined as FS $=i_{c r} / i$, when using graphical methods. Whereas Powrie (2004) suggested values of FS between 1.25 and 1.5 for Norwich Crag fine sand for a dewatering system design. In this example FS $=1.04 / 0.3=3.5$, and in the following a FS $\geq 2$ will be adopted as acceptable.

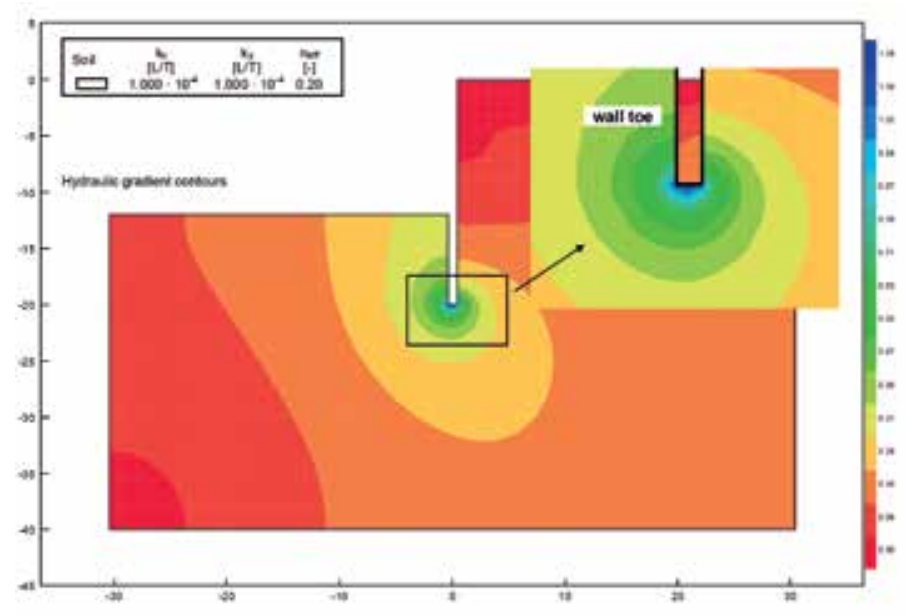

Figure 4: Distribution of hydraulic gradients around the diaphragm wall

Repeating the analysis for the excavation sequence depicted in Figure 1, it makes possible to construct a plot of $i$ versus the excavation depth $H$ as shown in Figure 5 . In that form, a criterion has to be adopted to define the value of $i$ for which the excavation is safe against piping. $i$ always results higher at the wall toe than at the excavation bottom. In Figure 5 it can be observed that at the wall toe values of $i>1\left(\approx i_{c r}\right)$ occur for $H>10 \mathrm{~m}$. Whether this is a local phenomenon or will propagate as piping eroding soil upwards needs to be assessed by $i$ along the soil next to the 
wall up to the surface. From the results shown in Figure 5 , propagating piping from the wall toe to the surface will induce failure for excavations depths $H$ beyond $16 \mathrm{~m}$ resulting in $i \geq 1$.

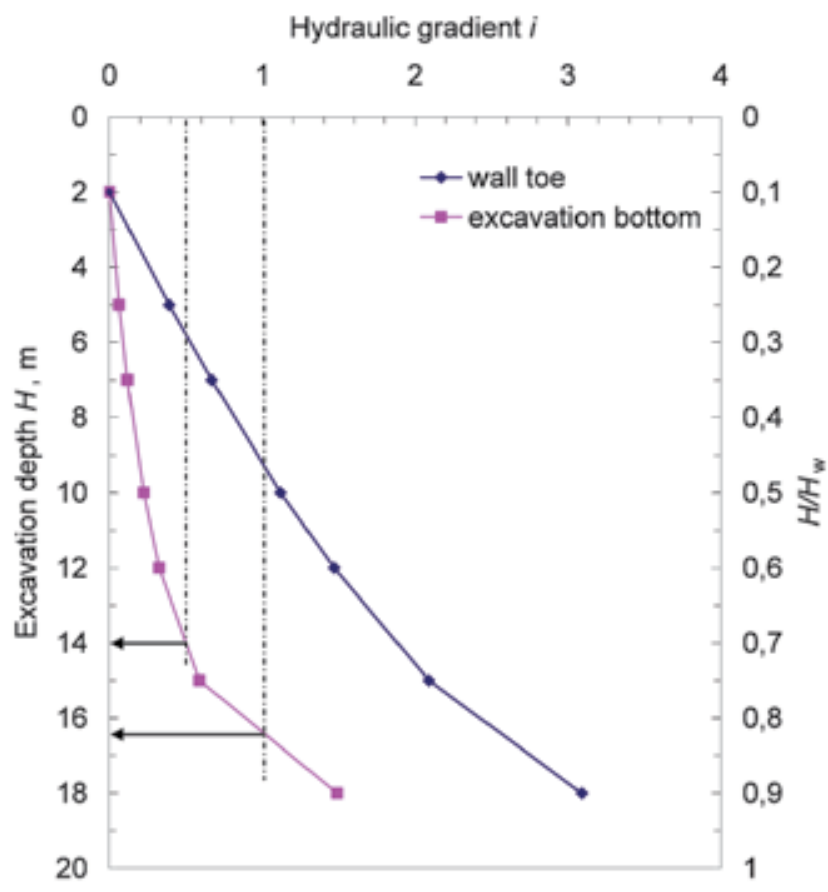

Figure 5: Hydraulic gradient $i$ versus excavation depth $H$ in an isotropic granular soil ( $H_{w}$ is the wall height)

\section{Results of piping safety factor}

To evaluate hydraulic stability it is usual in engineering practice to express $i$ results in terms of a piping factor of safety FS as a function of the excavation depth $H$. Figure 6 shows FS versus $H$ and $H / H_{w}$ in which FS is also a function of the soil buoyant unit weight $\gamma^{\prime}$. It can be observed that the soil unit weight effect on the FS is slightly more significant for the excavation bottom than for the wall toe. The values of $\gamma^{\prime}$ analysed: $10.2,9.2$ and $8.2 \mathrm{kN} / \mathrm{m}^{3}$, result in values of $i_{c r}$ of 1.04, 0.94 and 0.84, respectively. Adopting for example a piping factor of safety FS $=2$ for the excavation bottom, a maximum excavation depth of $14 \mathrm{~m}$ with a wall embedment $d$ of $6 \mathrm{~m}$, is obtained. As previously presented, for a $\mathrm{FS}=3.5$ results a maximum excavation depth of 12 $\mathrm{m}$ and $d=8 \mathrm{~m}$.

\section{Pore water pressure $u$}

In structural analysis of diaphragm walls it is customary the use of hydrostatic pore water pressures. However, due to seepage during excavation hydrodynamic pore

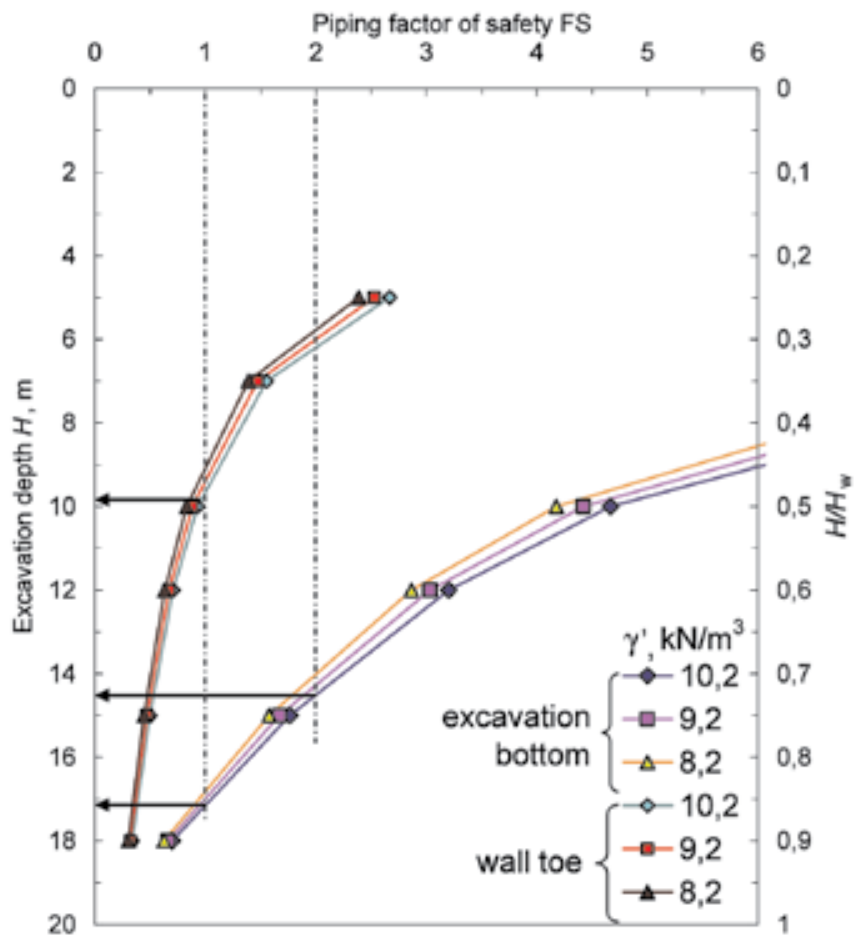

Figure 6: Piping factor or safety FS versus excavation depth $H$, showing variation with buoyant unit weight

water pressures can occur. In Figure 7, comparisons of hydrodynamic and hydrostatic pore pressures are shown. Pore pressure distributions on the excavation side shown in Figure 7a indicates that hydrodynamic pore pressures are always larger than the hydrostatic pore pressures due to upward flow. This reduces effective stresses, hence the soil shear strength and passive earth pressures. Conversely, Figures $7 \mathrm{~b}$ and $7 \mathrm{c}$ show that behind the wall downward flow reduces the hydrodynamic $u$ and the net pore pressure $u_{\text {net }}$ respect to the hydrostatic $u$. $u_{n e t}$ is the difference between $u$ behind the wall and $u$ in front of the wall. It can be observed in Figure $7 \mathrm{c}$ that the hydrostatic $u_{\text {net }}$ distributions form an envelope of the hydrodynamic $u_{\text {net }}$ distributions. Therefore, structural analysis carried out for the case when the basement is already built also covers the excavation sequence in terms of $u_{\text {net }}$.

Note that the $u$ distributions shown in Figures $7 \mathrm{~b}$ and $7 \mathrm{c}$ do not start at the constant $2 \mathrm{~m}$ aquifer level, but at different depths which reflects the drawdown of the water table level due to the lack of vertical recharge behind the diaphragm wall as shown in Figure 2b. As previously mentioned, for different conditions (excavation geometry, soil permeability and recharge source distance) the drawdown is likely to change. 
a)

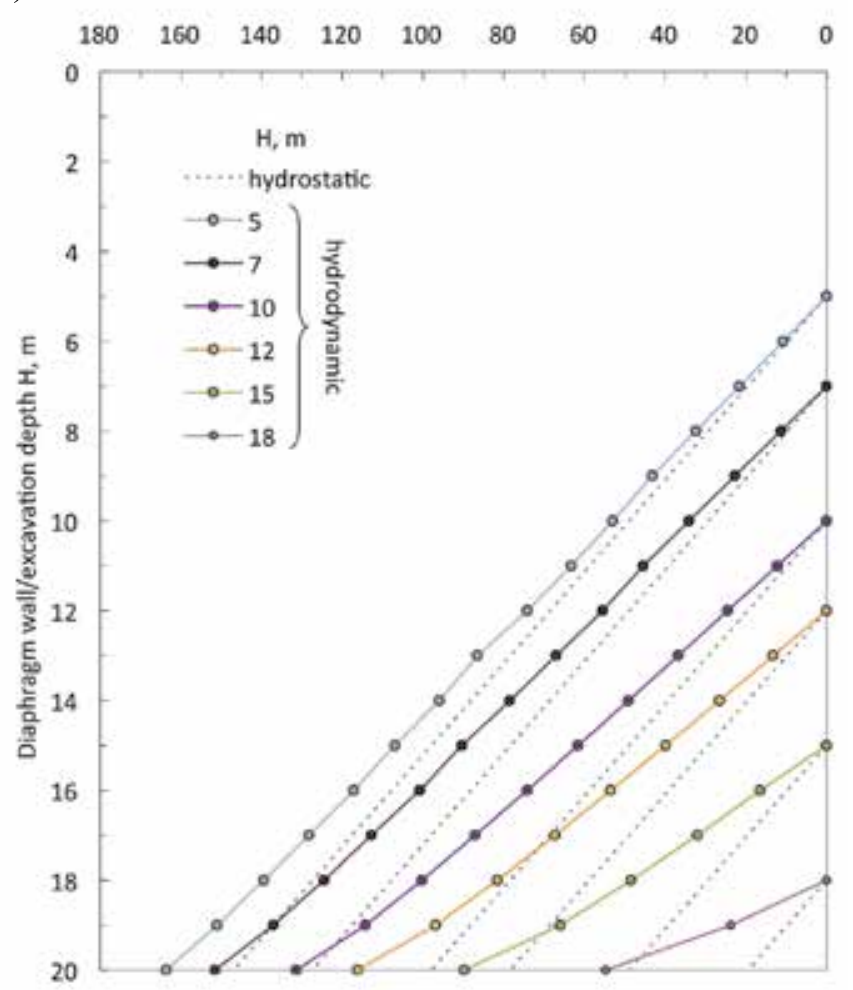

b) Pore pressure $\mathrm{u}, \mathrm{kPa} / \mathrm{m}$

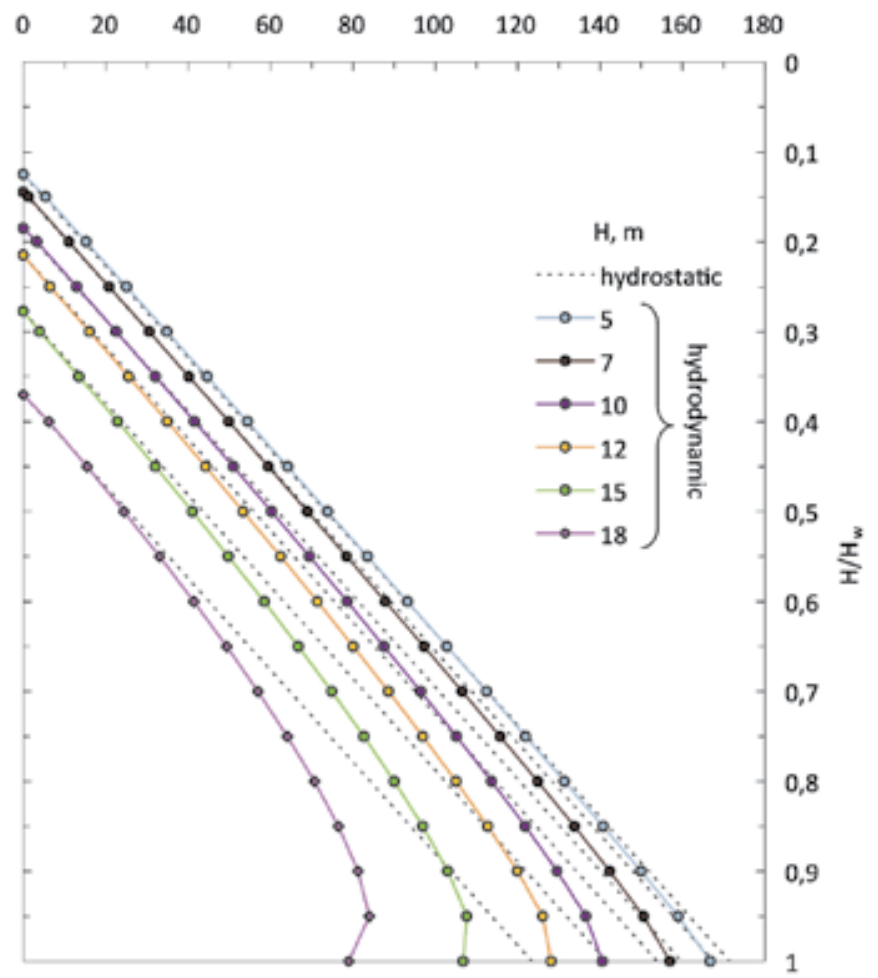

Net pore pressure $\mathrm{u}_{\text {net }}, \mathrm{kPa} / \mathrm{m}$

c)

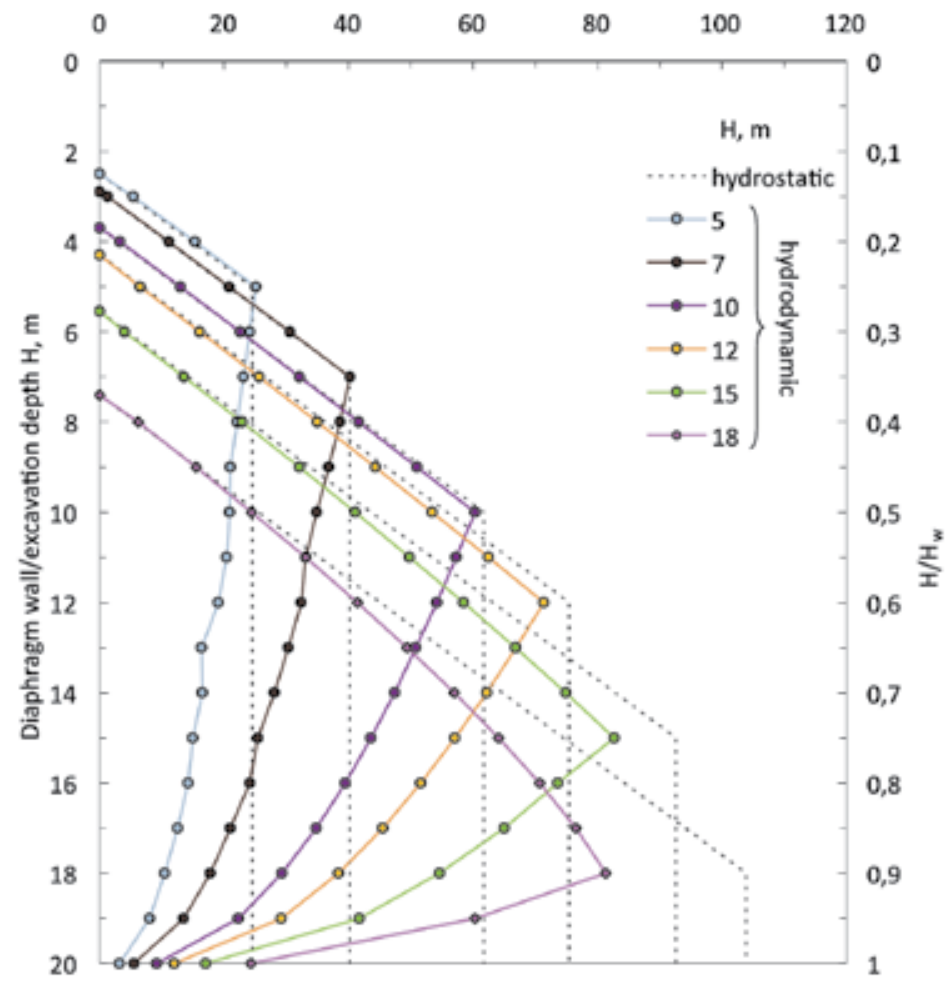

Figure 7: Hydrodynamic and hydrostatic pore pressure distributions on the a) excavation side, b) behind the wall and c) net pore pressure against the wall 


\section{Soil anisotropy}

Sedimentary deposits such as marine, alluvial, fluvial or lacustrine deposits are formed by successive layers one above the other. This layered system creates preferential horizontal flow paths, inducing higher permeability in this direction respect to the vertical direction. Anisotropy can also exist in the vertical direction, increasing gradually $k$ with depth due to higher confining stresses. This latter type of anisotropy is not considered in this study.

In an attempt to assess the effect of permeability anisotropy, a constant value of the horizontal coefficient of permeability $k_{h}=10^{-3} \mathrm{~m} / \mathrm{s}$ is introduced in the calculations, whilst keeping $k_{v}=10^{-4} \mathrm{~m} / \mathrm{s}$ as well as keeping the same conditions used before. Figure 8 shows $i$ versus $H$ and $H / H_{w}$ at the wall toe and excavation bottom, comparing isotropic and anisotropic conditions. It can be observed that under this anisotropic permeability conditions the maximum basement depth should be reduced from 16 to $14 \mathrm{~m}$ in order to avoid piping failure.

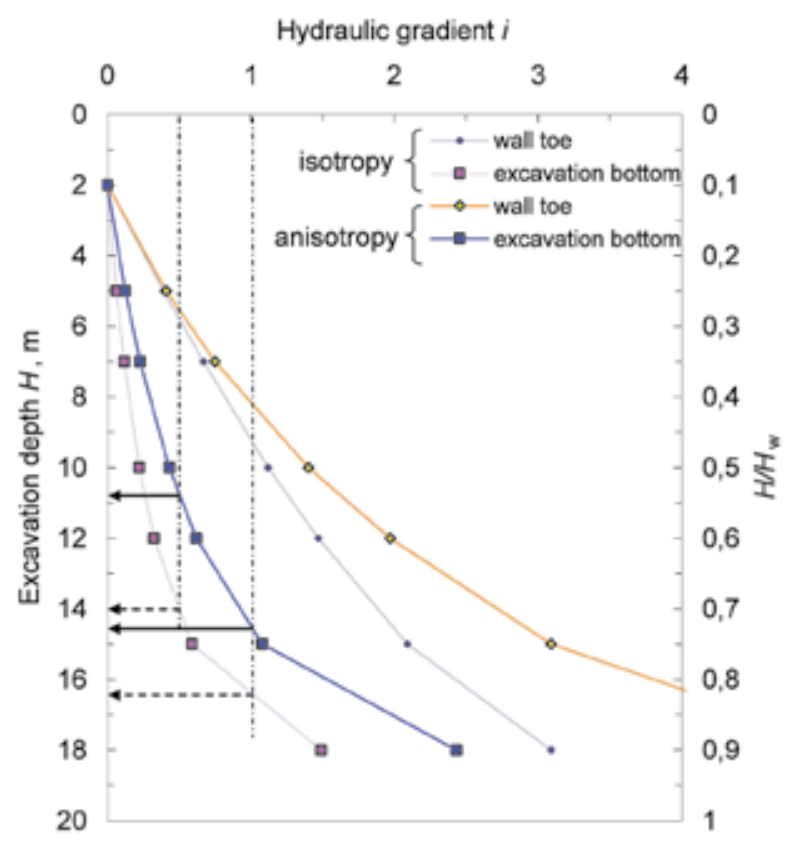

Figure 8: Variation of the hydraulic gradient $i$ with excavation depth $H$ and $H / H_{w}$, in an isotropic and anisotropic granular soil

In terms of the piping factor of safety $\mathrm{FS}$ and also evaluating the effect of $\gamma^{\prime}$, Figure 9 shows that for the excavation bottom assuming anisotropic permeability and $\mathrm{FS}=2$, a maximum basement depth of $11 \mathrm{~m}$ is obtained, instead of $14 \mathrm{~m}$ as in the isotropic case. Therefore, anisotropic conditions of the soil permeability can have an important effect in the hydraulic stability of excavations retained by diaphragm walls. In situ and laboratory testing for diaphragm wall projects should include determinations of permeability in vertical and horizontal directions.

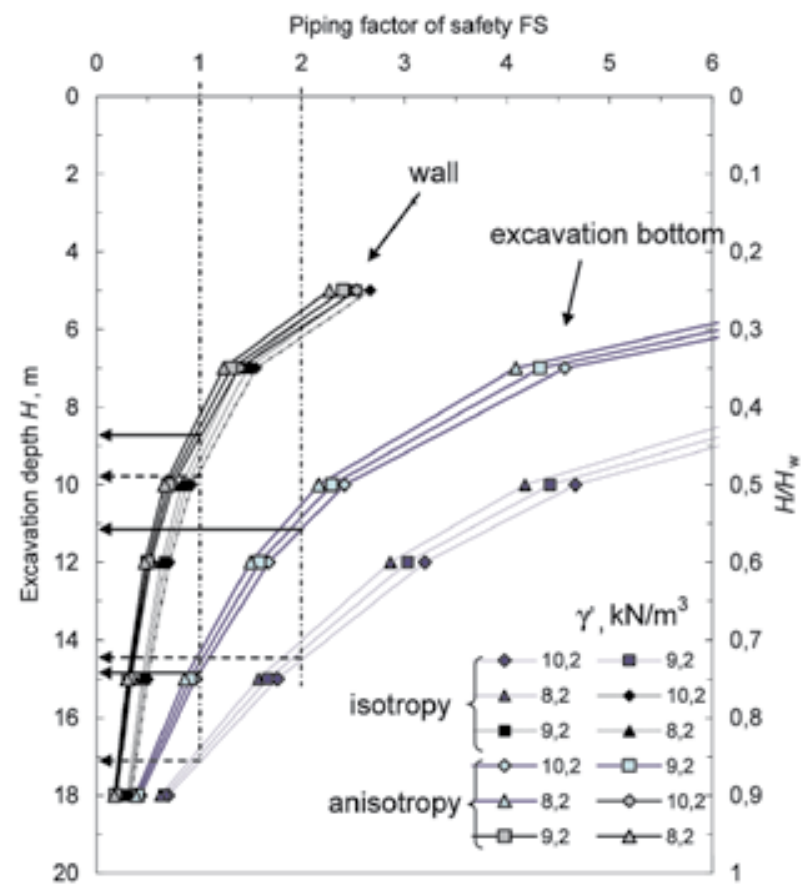

Figure 9: Piping factor or safety FS versus excavation depth $H$ and $H / H_{w}$, showing variation with buoyant unit weight $\gamma^{\prime}$ and isotropic and anisotropic permeability

\section{Flow rate}

As part of the seepage analysis the flow rate $q$ entering the excavation can be determined. The flow rate is evaluated in the mesh nodes along the excavation bottom and subsequently summed up to obtain $q$. A graphical calculation is also possible from flow nets as $q=k \Delta h N_{f} / N_{e}$, where $N_{f}$ and $N_{e}$ are the number of flow channels and the number of equipotential drops, respectively. This result is relevant for designing a pumping system to allow construction on a dry excavation. Since the problem is analysed in plane conditions, the real 3D case may differ from this approximation especially due to corner effects (for 3D analyses with constant horizontal water level behind the excavation see Aulbach and Ziegler, 2013b). Then, observing Figure 10, in the isotropic case and for $H=12 \mathrm{~m} \rightarrow q \approx 2 \mathrm{~m}^{3} / \mathrm{hr} / \mathrm{m}$, and the total flow rate $Q$ to be pumped out becomes $80 \mathrm{~m}^{3} / \mathrm{hr}$ (for a $40 \mathrm{~m}$ perimeter). It is important to note that $Q$ is directly proportional to the coefficient of permeability $k$ (from Darcy's law), therefore a change in one order of magnitude in $k$ will also change 


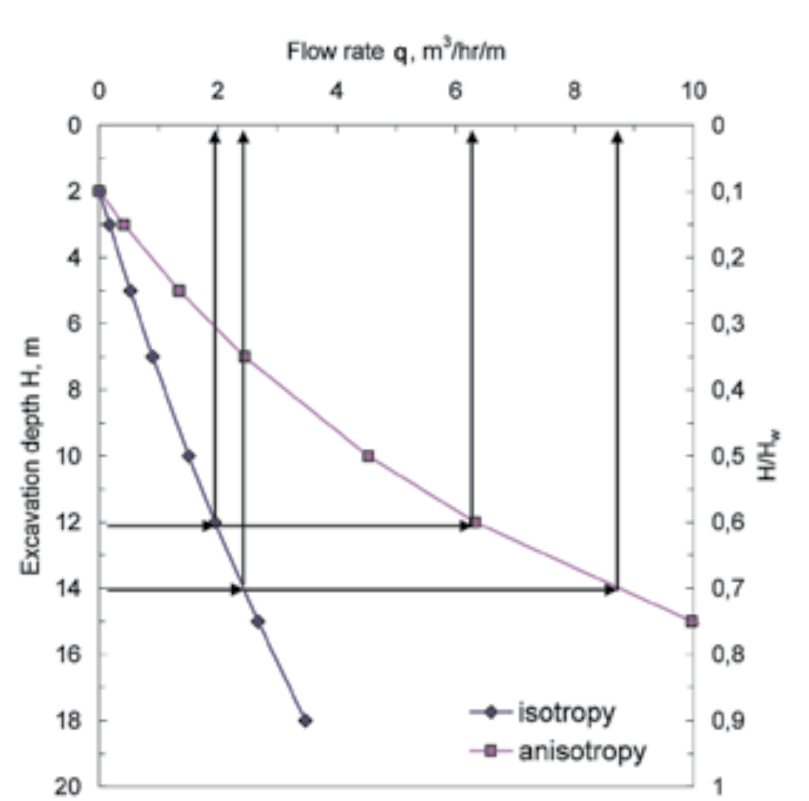

Figure 10: Flow rate $q$ entering the excavation as a function of the excavation depth $H$ and $H / H_{w}$

in the same order $Q$. Figure 10 also shows the anisotropic case introduced above. It is clear to observe the significant increase of $Q$ (three times for $H=12 \mathrm{~m}$ and almost four times for $H=14 \mathrm{~m}$ ), when $k_{h}$ diminishes in one order of magnitude to $10^{-3} \mathrm{~m} / \mathrm{s}$.

\section{Final remarks}

Hydraulic stability analyses are somewhat overlooked in diaphragm wall projects when compared with structural stability, which is normally more thoroughly evaluated during excavation and for permanent conditions. In this study, a generic problem of seepage around an impervious retaining structure is presented, which involve the assessment of hydraulic gradients, piping factor of safety, flow rates and pore water pressures. This methodology can assist in the evaluation of hydraulic stability of diaphragm walls by defining allowable maximum excavation depths and minimum wall embedment depths to avoid piping failure. Furthermore, anisotropic soil permeability can have a detrimental effect on the wall and excavation stability if it is not considered in seepage analyses. Further research is needed to address other boundary conditions to the ones used in this study for instance analysing the effect of the horizontal distance of the wall from the aquifer recharge and assuming a fixed excavation depth with variable wall embedment. It is also suggested comparisons of the piping method results with the Terzaghi method of hydraulic heave and the analysis of stratified soil conditions.

\section{References}

Aulbach, B. and Ziegler, M. (2013a). Hydraulic heave - Formula to determine the required embedded length. Bautechnik 90 (10), 631-641 (in German)

Aulbach, B. and Ziegler, M. (2013b). Simplified design of excavation support and shafts for safety against hydraulic heave. Geomechanics and Tunnelling 6(4), 362-374

BS 8004 (1986). Code of Practice for Foundations. British Standards Institution, Milton Keynes, UK

EAB (2008). Recommendations on Excavations. Deutsche Gesellschaft für Geotechnick e.V., $2^{\text {nd }}$ edition, Ernst \& Sohn

EAU (2006). Recommendations of the Committee for Waterfront Structures, Harbours and Waterways. Committee for Waterfront Structures of the Society for Harbour Engineering and the German Society for Soil Mechanics and Foundation Engineering, Berlin: Ernst \& Sohn

GE Ground Engineering (2009). Ground anchors could hold key to Cologne metro collapse. News April 2009

GGU-SS-FLOW2D (2008). Modelling of groundwater flow using finite elements in two-dimensional systems. Version 9. Civilserve GmbH, Steinfeld

Griffiths, D.V. (1994). Seepage beneath unsymmetric cofferdams. Géotechnique 44, No. 2, 297-305

Harr, M.E. (1990). Groundwater and seepage. Dover publications, New York

Marsland, A. (1953). Model experiments to study the influence of seepage on the stability of a sheeted excavation in sand. Géotechnique 3, Issue 6, 223-241

McNamee, J. (1949). Seepage into a sheeted excavation. Géotechnique 1, Issue 4, 229-241

NCE New Civil Engineer (2009). Diaphragm walls probed after Cologne collapse. 12 March 2009

NCh 3206 (2010). Geotecnia-excavaciones, entibaciones y socalzados. INN, Chile (in Spanish)

Powrie, W. (2004). Soil Mechanics. Concepts \& Applications. Spon Press

Terzaghi, K. (1943). Theoretical soil mechanics. Wiley and Sons. New York

Ziegler, M., Aulbach, B., Heller, H. and Kuhlmann, D. (2009). The hydraulic heave - Design charts for determining the necessary embedded length. Bautechnik 86(9), 529 - 541 (in German) 